\title{
Air pollutants and hospital admission due to pneumonia in children: a time series analysis
}

\author{
Laís Salgado Vieira de Souza ${ }^{1}$, Luiz Fernando Costa Nascimento2* \\ ${ }^{1}$ Medical Student, Department of Medicine, Universidade de Taubaté (Unitau), Taubaté, SP, Brazil \\ 2PhD in Public Health. Assistant Professor, Department of Medicine, Unitau, Taubaté, SP, Brazil
}

Study conducted at the Department of Medicine at Universidade de Taubaté (Unitau), Taubaté, SP, Brazi

Article received: 6/4/2014 Accepted for publication: 10/22/2014

${ }^{\star}$ Correspondence: Address: Avenida Tiradentes, 500 Taubaté, SP - Brazil Postal code: $12030-180$ Phone/fax: +55 12 3625-4271 luiz.nascimento@pq.cnpq.br

Financial support: São Paulo State Research Foundation (Fapesp)

http://dx.doi.org/10.1590/1806-9282.62.02.151

\section{SUMmARY}

Objective: The aim of this study was to estimate the association between exposure to air pollutants and hospitalization for pneumonia among children in a medium-sized city located in the sugar cane plantation region of São Paulo State. Methods: An ecological time-series study was conducted with daily data of hospitalization for pneumonia including children aged 10 years or younger living in Araraquara, state of São Paulo, from January $1^{\text {st }}$, 2010, to November $30^{\text {th }}, 2012$. To estimate the association between hospitalization due to pneumonia and particulate pollutants with aerodynamic diameter less than $10 \mu \mathrm{m}$, nitrogen dioxide and ozone, relative risks for hospitalization according to a generalized additive model of Poisson regression, with Lags of up to five days, were calculated. A percentage increase (PI) was obtained for relative risk (IRR - increase on relative risk) of hospitalization at each $10 \mu \mathrm{g} / \mathrm{m}^{3}$ increment in each air pollutants adjusted for the remaining.

Results: A total of 234 hospitalizations were recorded during these three years. There was a strong association between hospitalization and $\mathrm{PM}_{10}$ and $\mathrm{NO}_{2}$. The PI in relative risk was $15 \%$ to $\mathrm{PM}_{10}$ in Lag 0 and $7 \%$ points in Lag 1 for $\mathrm{NO}_{2}$.

Conclusion: There was evidence of the action of air pollutants on hospitalization for pneumonia in a medium-sized city located in a region affected by air pollution from sugarcane burning and the data presented here provide subsidies for the implementation of public policies aiming to decrease this risk.

Keywords: Pneumonia, air pollutants, particulate matter, nitrogen dioxide, child health, time-series studies.

\section{INTRODUCTION}

It is known that chronic exposure of children and adolescents to air pollution leads to decreased development and lung function, and also an increased number of episodes of respiratory disease and hospitalizations. ${ }^{1,2}$ Air pollutants associated with these effects include nitrogen dioxide $\left(\mathrm{NO}_{2}\right)$, ozone $\left(\mathrm{O}_{3}\right)$ and particulate matter with an aerodynamic diameter less than $10 \mu \mathrm{m}\left(\mathrm{PM}_{10}\right)^{3}{ }^{3}$

Exposure to $\mathrm{PM}_{10}$ is associated with increased morbidity due to local inflammation, injury by oxidative stress and endothelial dysfunction. ${ }^{4}$ Particulate matter originating mainly from burning fossil fuels and biomass (such as burning of sugarcane straw), is associated with increased symptoms and respiratory disease, increased incidence of asthma and pneumonia, and infant mortality. 5,6

Exposure to $\mathrm{NO}_{2}$ alters the mucociliary clearance mechanism, particle transport, and local immunity, favoring the onset of respiratory infections. ${ }^{7}$ This compound is formed during combustion processes; therefore, in large urban centers, vehicles are usually the major emitters.

$\mathrm{NO}_{2}$ also plays an important role in the generation of $\mathrm{O}_{3}$ in troposphere, it is considered toxic and harmful to health, and is associated with decreased lung function, increased airway reactivity and inflammation and impaired macrophage function. ${ }^{5} \mathrm{O}_{3}$ is a powerful oxidant that causes irritation to the eyes and respiratory tract, reducing lung capacity.?

It is believed that the adverse effects caused by exposure to environmental pollutants have a Lag of behavior, that is, an individual exposed to a pollutant today is likely to present some respiratory disease a few days later. ${ }^{8}$

The vast majority of studies in Brazil evaluating air pollution and respiratory diseases were developed in large urban centers, including São Paulo, Rio de Janeiro and Curitiba. ${ }^{8-12}$ 
However, there are few studies on the effects of air pollution outside of major urban centers, especially in areas where there is biomass burning such as sugarcane straw. ${ }^{13-15}$

Thus, the objective of this study was to estimate the association between exposure to air pollution and hospital admissions for pneumonia in children living in Araraquara, a medium-sized municipality in the state of São Paulo, in the period from January 2010 to November 2012.

\section{Methods}

The study was conducted in the municipality of Araraquara, considered medium size, with a population around 210,000 inhabitants, located in the central portion of the state of São Paulo (21 ${ }^{\circ} 47^{\prime} 40^{\prime \prime}$ S, 48¹0'32” O). It is located $273 \mathrm{~km}$ away from the state capital, and covers the area of $1,003.674 \mathrm{~km}^{2}$. Araraquara has a vehicle fleet estimated at about 150 thousand vehicles. This city has an intense activity linked to the sugar and alcohol industry and, between the months of April and November, there is burning of sugarcane straw.

This is an ecological time series analysis, in which daily hospitalizations for pneumonia $\left(10^{\text {th }}\right.$ revision of the International Statistical Classificationof Diseases and Related Health Problems, ICD-10, J12 to J18 codes) in children aged 10 years or younger, from January $1^{\text {st }}, 2010$, to November $30^{\text {th }}, 2012$, were selected. These data were obtained from the database of the SUS Department of Informatics (Datasus) ${ }^{16}$

Daily data of pollutants $\mathrm{NO}_{2}, \mathrm{O}_{3}$ and $\mathrm{PM}_{10}$, as well as temperature and humidity were obtained from the São Paulo State Environmental Sanitation Company (Cetesb). ${ }^{17}$

Both descriptive and statistical analyses, with a Lag from 0 to 5 days, were conducted. The estimated risk for hospitalization due to pneumonia caused by exposure to pollutants was done using a generalized additive Poisson regression model (GAM). For this, the air pollutants were always analyzed together in a multi-pollutant model, adjusted for humidity and temperature. The relative risk of hospitalization was obtained at increments of $10 \mu \mathrm{g} / \mathrm{m}^{3}$ (IRR) for each pollutant, adjusted to the remaining using the following formula:

$$
\operatorname{IRR}(\%)=\left(\exp ^{10 \times \beta}-1\right) \times 100
$$

In the equation, $\beta$ is the coefficient obtained from GAM adjusted for each pollutant in relation to the remaining. The software used for analysis was Statistica 7.

\section{RESULTS}

During the study period there were 234 hospitalizations of children with pneumonia, aged 0 to 10 years and resident in Araraquara. The daily average was 0.22 admis- sions $(\mathrm{SD}=0.48)$, ranging from 0 to 3 . The months with the highest hospitalizations numbers were April, May and June 2010 with 10 admissions each, August 2011 with 11, and May 2012 with 25. This distribution coincides with the months of sugarcane straw burning that occur each year between April and November. There was no record in 27 days ( $2.50 \%$ of days) of temperature and humidity, 30 days (2.82\%) for $\mathrm{O}_{3}, 88$ days (8.26\%) for $\mathrm{NO}_{2}$ and 50 days (4.69\%) for $\mathrm{PM}_{10}$ within the period of study. Information on hospital admissions caused by pneumonia was available throughout the study period. The lacking data did not compromise the final results in this study. A descriptive analysis of the variables is shown in Table 1.

TABLE 1 Descriptive analysis of atmospheric and climatic variables, Araraquara, 2010-2012.

\begin{tabular}{lll} 
& Mean (SD) & Min - Max \\
\hline $\mathrm{PM}_{10}\left(\mu \mathrm{g} / \mathrm{m}^{3}\right)$ & $35.7(21.6)$ & $5.0-150.0$ \\
\hline $\mathrm{NO}_{2}\left(\mu \mathrm{g} / \mathrm{m}^{3}\right)$ & $56.5(28.5)$ & $8.0-185.0$ \\
\hline $\mathrm{O}_{3}\left(\mu \mathrm{g} / \mathrm{m}^{3}\right)$ & $78.0(25.0)$ & $13.0-182.0$ \\
\hline Temperature $\left({ }^{\circ} \mathrm{C}\right)$ & $28.8(3.6)$ & $13.9-38.6$ \\
\hline Humidity $(\%)$ & $43.7(16.3)$ & $10.0-99.0$ \\
\hline
\end{tabular}

SD: Standard deviation.

Another point that draws attention is the high average values for concentration of pollutants, possibly due to the burning of sugarcane straw that occurs in this region. Regarding $\mathrm{PM}_{10}$ values, there were 103 days in 2010, 84 days in 2011 and 33 days in 2012 that were above the standard limit of air quality according to the World Health Organization $(\mathrm{WHO})^{18}$ with a daily average of $\left(50 \mu \mathrm{g} / \mathrm{m}^{3}\right)$. Nitrogen dioxide exceeded the limits of the annual arithmetic average for the three years of study $\left(40 \mu \mathrm{g} / \mathrm{m}^{3}\right) . \mathrm{O}_{3}$ in turn, presented 60 days in 2010, 31 days in 2011 and 86 days in 2012 above the average limit for 8 hours $\left(100 \mu \mathrm{g} / \mathrm{m}^{3}\right)$.

Distributions of daily concentrations of pollutants quantified in Araraquara show seasonal characteristics for $\mathrm{PM}_{10}$ and $\mathrm{NO}_{2}$ (data not shown).

Table 2, which displays the Pearson correlation matrix for the selected variables, it can be seen that hospitalizations are positively correlated with the concentrations of $\mathrm{PM}_{10}$ and $\mathrm{NO}_{2}$, and that the pollutants are significantly correlated to each other. All pollutants present negative and significant correlations with the content of relative humidity, and positive and significant correlations with temperature.

Based on Poisson regression, with the three pollutants analyzed together, adjusted for temperature and humidity, the authors obtained regression coefficients and their respective standard errors for each pollutant in each Lag structure (Table 3). 
TABLE 2 Correlation matrix for pollutants, climate variables and hospitalization, Araraquara, 2010-2012.

\begin{tabular}{lllllll} 
& Inter\# & $\mathbf{P M}_{\mathbf{1 0}}$ & $\mathbf{T e m p}$ & Humid & $\mathbf{O}_{3}$ & $\mathbf{N O}_{2}$ \\
\hline Inter\# & 1.00 & $0.10^{*}$ & -0.05 & -0.04 & -0.01 & $0.07^{*}$ \\
\hline $\mathrm{PM}_{10}$ & - & 1.00 & $0.23^{*}$ & $-0.64^{*}$ & $0.55^{*}$ & $0.58^{*}$ \\
\hline $\mathrm{Temp}$ & - & - & 1.00 & $-0.54^{*}$ & $0.55^{*}$ & $0.16^{*}$ \\
\hline Humid & - & - & - & 1.00 & $-0.64^{*}$ & $-0.57^{*}$ \\
\hline $\mathrm{O}_{3}$ & - & - & - & - & 1.00 & $0.45^{*}$ \\
\hline $\mathrm{NO}_{2}$ & - & - & - & - & - & 1.00 \\
\hline
\end{tabular}

* $\mathrm{p}<0.05$; \#Admissions; Temp: Temperature; Humid: Humidity.

The association that occurs in the second and third days after exposure to $\mathrm{PM}_{10}$, and in the first and fifth day after exposure to nitrogen dioxide, is noteworthy. Ozone displays a paradoxical pattern.

Relative risks and their respective confidence intervals of $95 \%$ for hospitalization, obtained based on multipollutant model for the increase of $10 \mu \mathrm{g} / \mathrm{m}^{3}$ of each pollutant, are shown in Figure 1.

The effect of exposure to $\mathrm{PM}_{10}$ as a risk factor for Lag 0 (same day of exposure) and on the third day of exposure (Lag 3) is observed. Increments of $10 \mu \mathrm{g} / \mathrm{m}^{3}$ in this pollutant lead to increase of $15 \%$ in relative risk. The mechanism that appears to explain this is the acute release of inflammatory mediators. $\mathrm{NO}_{2}$ represents a risk factor for $\operatorname{Lag} 1$ and $\operatorname{Lag} 5$, and $10 \mu \mathrm{g} / \mathrm{m}^{3}$ increments of this pollutant lead to increase of $7 \%$ in relative risk. $\mathrm{O}_{3}$, in turn, did not behave as a risk factor.

\section{Discussion}

There are few studies on the effects of pollution as a cause of hospitalization for pneumonia, especially in mid-sized cities located in regions of sugarcane plantation affected by straw burning, such as Araraquara.

Time-series studies show the association between levels of air pollutants and number of hospitalization for respiratory diseases in Brazilian state capitals including São Paulo, ${ }^{6,9,10}$ Campo Grande, ${ }^{19}$ Rio de Janeiro ${ }^{20}$ and Curitiba ${ }^{8}$. But there are few studies conducted in cities located in regions producing sugarcane correlating the effects of straw burning and its impact on population health. ${ }^{21,22}$

In the present study, it was found that the distribution of air pollutants has seasonal aspects, and the average levels of these pollutants were below those observed by Braga et al. ${ }^{9}$ and Bakonyi et al. ${ }^{8}$, although higher than those found by Souza et al. ${ }^{19}$ in a study carried out in Campo Grande, MS, and by Moura et al. ${ }^{20}$ in Rio de Janeiro. This result is quite interesting since Araraquara is a medium-sized city located in the state of São Paulo. Such higher levels of pollutants compared to large urban centers can be explained by the location in one of the largest regions of sugarcane culture, where the practice of burning straw is widely used.

In the three years of study, all analyzed pollutants exceeded the limits imposed by the WHO. In the case of $\mathrm{PM}_{10}$, annual exposure levels above $70 \mu \mathrm{g} / \mathrm{m}^{3}$ are associated with significant deleterious health effects, leading to up to $15 \%$ increased mortality. $\mathrm{O}_{3}$ presented an average concentration of $78 \mu \mathrm{g} / \mathrm{m}^{3}$ and time series studies found increased mortality close to $0.3-0.5 \%$ for each $10 \mu \mathrm{g} / \mathrm{m}^{3}$ increment in its concentration beginning with $70 \mu \mathrm{g} / \mathrm{m}^{3}$. Additionally, studies show that chronic exposure to $\mathrm{NO}_{2}$ at annual average concentrations above $40 \mu \mathrm{g} / \mathrm{m}^{3}$ are associated with increased symptoms in asthmatic children. ${ }^{18}$

$\mathrm{PM}_{10}$ was significantly associated hospitalizations for pneumonia both on the same day of exposure and on the third day after it. The pollutant's effect is immediate, i.e. in the day of exposure, but can also be noticed days later. Negrisoli et al. ${ }^{14}$ observed this association at Lag 4 in a study conducted in Sorocaba, SP, on hospitalizations due to pneumonia, and Nascimento et al. ${ }^{3}$ noted that the ef-

TABLE 3 Coefficients and standard errors (SE) for environmental pollutants on every day of the analyzed Lag structure. Araraquara, SP, $2010-2012$.

\begin{tabular}{llll} 
& $\mathbf{P M}_{\mathbf{1 0}}$ & $\mathbf{N O}_{\mathbf{2}}$ & $\mathbf{O}_{3}$ \\
\hline & Coefficient (SE) & Coefficient (SE) & Coefficient (SE) \\
\hline Lag 0 & $0.01379(0.00441)^{*}$ & $0.00134(0.00312)$ & $-0.00799(0.00409)$ \\
\hline Lag 1 & $0.00820(0.00435)$ & $0.00695(0.00293)^{*}$ & $-0.00610(0.00408)$ \\
\hline Lag 2 & $0.00617(0.00435)$ & $0.00462(0.00305)$ & $-0.00794(0.00401)^{*}$ \\
\hline Lag 3 & $0.01013(0.00478)^{*}$ & $0.00478(0.00312)$ & $-0.01148(0.00395)^{*}$ \\
\hline Lag 4 & $0.00103(0.00512)$ & $0.00463(0.00326)$ & $-0.01102(0.00417)^{*}$ \\
\hline Lag 5 & $0.00419(0.00473)$ & $0.00613(0.00313)^{*}$ & $-0.00270(0.00421)$
\end{tabular}




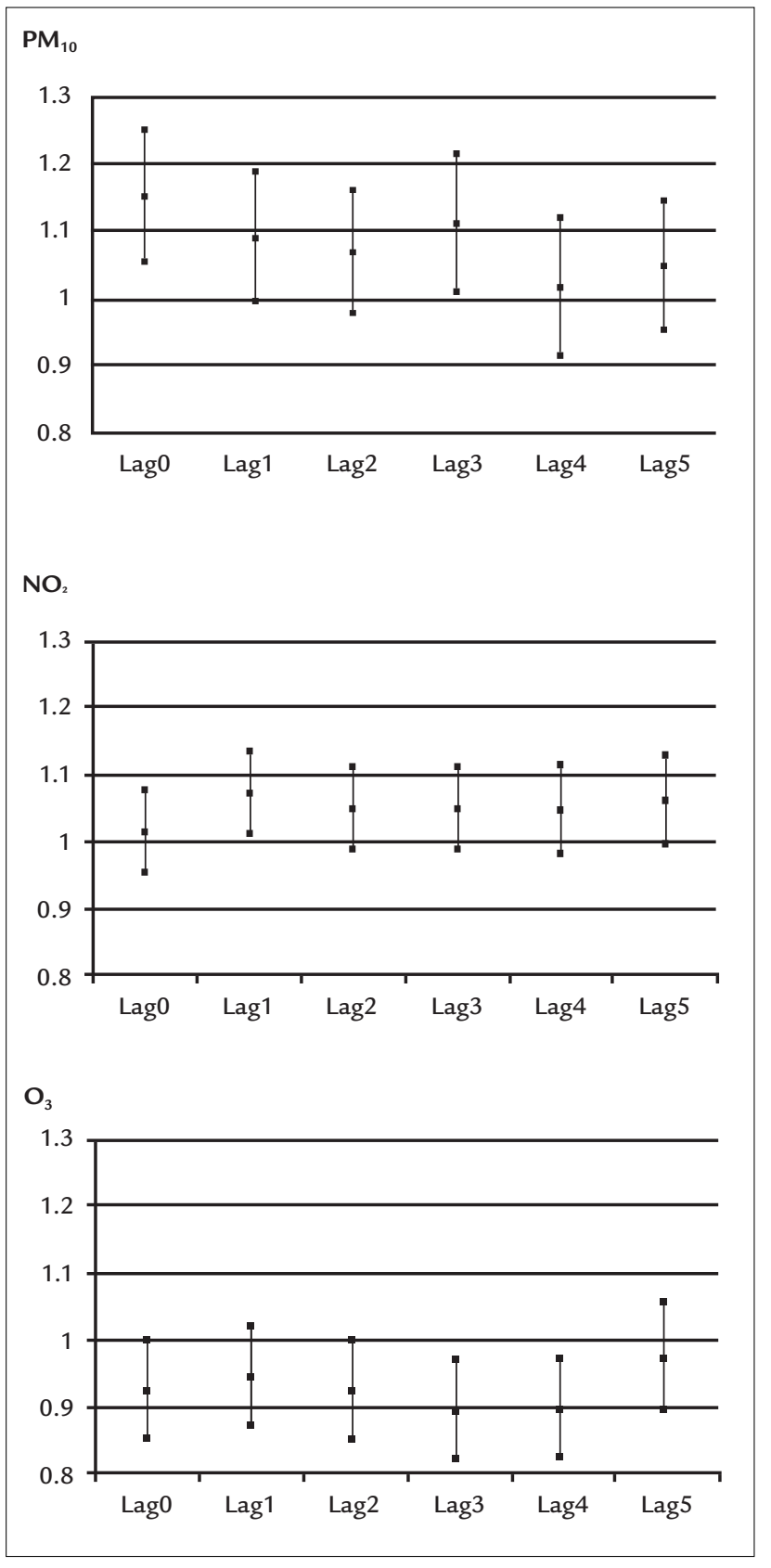

FIGURE 1 Relative risks for hospitalization caused by pneumonia due to increases of $10 \mu \mathrm{g} / \mathrm{m}^{3}$ in $\mathrm{PM}_{10}, \mathrm{NO}_{2}$ and $\mathrm{O}_{3}$ pollutants, with 0- to 5-day Lag. Araraquara, 2010-2012.

fects of $\mathrm{PM}_{10}$ on hospital admissions due to pneumonia in the city of São José dos Campos, SP, became relevant only three or four days after exposure.

In a study by Cesar et al., ${ }^{13}$ conducted in the municipality of Piracicaba, SP, the authors were able to observe that increments of $10 \mathrm{mg} / \mathrm{m}^{3}$ in the level of inhalable fine particulate matter $\left(\mathrm{PM}_{2.5}\right)$ are associated with increases of $7.9(\operatorname{Lag} 1)$ and $8.6 \%(\operatorname{Lag} 3)$ in hospitalizations due to respiratory diseases. Arbex et al. ${ }^{15}$ linked this increase to a $6 \%$ increase in demand for emergency service caused by pneumonia at a hospital in Araraquara, Brazil.

Nitrogen dioxide was associated with hospitalizations for pneumonia, presenting as a risk factor in the first and fifth day after exposure. The average values found in this study $\left(56.5 \mu \mathrm{g} / \mathrm{m}^{3}\right)$ were below those found for the municipality of São Paulo $\left(103 \mu \mathrm{g} / \mathrm{m}^{3}\right),{ }^{23}$ and above the results found in Sorocaba $\left(48.1 \mu \mathrm{g} / \mathrm{m}^{3}\right) .{ }^{14}$ Nevertheless, exposure to this pollutant in both cities was associated with hospitalization for pneumonia, with double the risk compared to our study. Moreover, a study conducted in Cubatão with a metering station for $\mathrm{NO}_{2}$, whose averages were around $27 \mu \mathrm{g} / \mathrm{m} 3$, failed to identify an association between exposure to $\mathrm{NO}_{2}$ and pneumonia in children. ${ }^{24}$ In a study conducted in Rio de Janeiro ${ }^{25}$ regarding pediatric emergency care in public health units, it was not possible to associate these services to exposure to $\mathrm{NO}_{2}$. Other comparisons were not possible due to the lack of studies in Brazil on exposure to $\mathrm{NO}_{2}$ and pediatric hospitalizations for pneumonia.

With regard to ozone, the pollutant was not statistically significant as a risk factor in any of the analyzed Lag structures. This result is consistent with studies conducted in Sorocaba ${ }^{14}$ and São José dos Campos ${ }^{26}$ where $\mathrm{O}_{3}$ represented no risk for hospitalization for asthma and pneumonia, respectively. However, a study by Bakonyi et al. ${ }^{8}$ revealed a statistically significant effect in the case of ozone, only for the mobile average of three days. This statistical difference may be due to the fact that their study variable were individuals aged 0-14 years treated for all respiratory causes, and not only pneumonia, and also the fact that they used mobile averages, not Lag, as in the present study.

A limitation in this study may result from the exclusion of hospitalizations in the context of health insurance and other funding sources other than the SUS, as well as pneumonia in children treated on an outpatient basis, that is, that did not result in hospitalization and thus not included in the study. In addition, errors in ICD coding of the disease may have contributed to an inaccurate accounting of cases. These limitations mentioned above could contribute to an underreporting of cases of the disease. It should be noted, however, that the Datasus is an official source of the Ministry of Health and the data provided by the portal serve as material for conducting epidemiological studies. The hospital records refer to the portion of the population that uses the public health service, which is the majority of the population. Errors in diagnosis or double counting of the same patient may have occurred.

Failures in the monitoring of pollutants during the study cause lack of data, both in isolated days and on con- 
secutive days. However, in ecological studies of time series with daily data, the absence of some of the figures did not affect the final results. Individual exposures to the gases analyzed were not considered, and their concentrations were treated as homogeneous throughout the municipality.

\section{Conclusion}

The results allowed us to associate $\mathrm{PM}_{10}$ and $\mathrm{NO}_{2}$ to the hospitalization of children aged 10 years or younger due to pneumonia in a mid-sized city located in an area affected by air pollution caused by the burning of sugarcane straw. These findings are important for the creation of health policies in the municipality, and reinforce the importance of incentives regarding a ban on such practice in sugarcane plantations.

\section{AcknOWLedgments}

To the Environmental Sanitation Technology Company (Cetesb) for making its database available, and the São Paulo State Research Foundation (Fapesp) for a scientific initiation scholarship (process 2013/11490-9).

\section{Resumo}

Poluentes atmosféricos e internações por pneumonia em crianças. Um estudo de série temporal

Objetivo: estimar a associação entre exposição a poluentes atmosféricos e internações por pneumonia em crianças de uma cidade de médio porte em região de plantio de cana-de-açúcar no Estado de São Paulo.

Métodos: estudo ecológico de séries temporais com dados de internação por pneumonia em crianças com até 10 anos de idade residentes em Araraquara, SP, de 1 de janeiro de 2010 a 30 de novembro de 2012. Para estimar a associação entre internações por pneumonia e material particulado (MP) com diâmetro aerodinâmico inferior a $10 \mu \mathrm{m}$, dióxido de nitrogênio e ozônio, foram calculados os riscos relativos para internação segundo modelo aditivo generalizado de regressão de Poisson, com defasagens de até cinco dias. Foi obtido o aumento percentual (ppt) no risco relativo (ARR - aumento no risco relativo) para internação segundo aumento de $10 \mu \mathrm{g} / \mathrm{m}^{3}$ para cada poluente ajustado para os demais.

Resultados: registraram-se 234 internações nos três anos de estudo. Houve forte associação entre as internações e o $\mathrm{MP}_{10}$ e o $\mathrm{NO}_{2}$. O ARR foi de 15 ppt para $\mathrm{MP}_{10}$ no mesmo dia da exposição e de 7 ppt no primeiro dia após a exposição ao $\mathrm{NO}_{2}$.
Conclusão: houve evidências da ação de poluentes do ar sobre internações por pneumonia em uma cidade de médio porte em região afetada por poluição do ar decorrente de queima da palha da cana-de-açúcar. Os dados apresentados fornecem subsídios para implantação de políticas públicas visando à diminuição desses riscos.

Palavras-chave: pneumonia, poluentes do ar, material particulado, dióxido de nitrogênio, saúde da criança, estudos de séries temporais.

\section{References}

1. Brauer M, Hoek G, Smit HA, Jongste JC, Gerritsen J, Postma DS, et al. Air pollution and development of asthma, allergy and infections in a birth cohort. Eur Respir J. 2007; 29(5):879-88.

2. Gauderman WJ, Avol E, Gilliland F, Vora H, Thomas D, Berhane K et al. The effect of air pollution on lung development from 10 to 18 years of age. $\mathrm{N}$ Engl J Med. 2004; 351(11):1057-67.

3. Nascimento LFC, Pereira LAA, Braga ALF, Módolo MCC, Carvalho JA. Efeitos da poluição atmosférica na saúde infantil em São José dos Campos, SP. Rev Saúde Pública. 2006; 40(1):77-82.

4. Pope CA, Dockery DW. Health effects of fine particulate air pollution: lines that connect. J Air Waste Manage Assoc. 2006; 56(6):709-42.

5. Committee of the Environmental and Occupational Health Assembly of the American Thoracic Society. Health effects of outdoor air pollution. Am J Respir Crit Care Med. 1996; 153(1):3-50.

6. Lin CA, Martins MA, Farhat SCL, Pope CA, Conceição GMS, Anastácio VM, et al. Air pollution and respiratory illness of children in São Paulo, Brazil. Pediatr Perinat Epidemiol. 1999; 13(4):475-88.

7. Arbex MA, Santos UP, Martins LC, Saldiva PH, Pereira LA, Braga AL. Air pollution and the respiratory system. J Bras Pneumol. 2012; 38(5):643-55.

8. Bakonyi SMC, Danni-Oliveira IM, Martins LC, Braga ALF. [Air pollution and respiratory diseases among children in the city of Curitiba, Brazil]. Rev Saúde Pública. 2004; 38(5):695-700.

9. Braga ALF, Conceição GMS, Pereira LAA, Kihi HS, Pereira JCR, Andrade MF, et al. Air pollution and pediatric respiratory hospital admissions in São Paulo, Brazil. J Environ Med. 1999; 1(2):95-102.

10. Braga ALF, Saldiva PHN, Pereira LAA, Menezes JJC, Conceição GMS, Lin $\mathrm{CA}$, et al. Health effects of air pollution exposure on children and adolescents in São Paulo, Brazil. Pediatr Pulmonol. 2001; 31(2):106-13.

11. Fioravante C. Estufa que exporta poluição. Rev Pesquisa FAPESP. 2002; 71:128-35.

12. Pereira LAA, Loomis D, Conceição GMS, Braga ALF, Arcas RM, Kishi HS et al. Association between air pollution and intrauterine mortality in São Paulo, Brazil. Environ Health Perspect. 1998; 106(6):325-9.

13. Cesar ACG, Nascimento LFC, Carvalho Jr JAD. Associação entre exposição ao material particulado e internações por doenças respiratórias em crianças. Rev Saúde Pública. 2013; 47(6):1209-12.

14. Negrisoli J, Nascimento LFC. Atmospheric pollutants and hospital admissions due to pneumonia in children. Rev Paul Pediatr. 2013; 31(4):501-6.

15. Arbex MA, Pereira LAA, Carvalho-Oliveira R, Saldiva PHN, Braga ALF. The effect of air pollution on pneumonia-related emergency department visits in a region of extensive sugar cane plantations: a 30-month time-series study J Epidemiol Community Health. 2014; 68(7):669-74.

16. Brasil. Departamento de Informações e Informática do Sistema Único de Saúde, DATASUS. [cited 2014 May 20]. Available from: http://www2.datasus. gov.br/DATASUS/index.php.

17. Companhia de Tecnologia de Saneamento Ambiental, CETESB. [cited 2013 Sep 20]. Available from: http://www.cetesb.sp.gov.br.

18. World Health Organization. WHO Air Quality Guidelines for particulate matter, ozone, nitrogen dioxide and sulfur dioxide. Global Update 2005 Summary of risk assessment. [cited 2014 May 20]. Available from: http:// whqlibdoc.who.int/hq/2006/WHO_SDE_PHE_OEH_06.02_eng.pdf.

19. Souza A, Schujmann E, Fachel JMG, Fernandes WA. Indicadores ambientais e doenças respiratórias em crianças. Mercator. 2013; 12(27):101-9. 
20. Moura M, Junger WL, Mendonça GAS, Leon AP. Air quality and emergency pediatric care for symptoms of bronchial obstruction categorized by age bracket in Rio de Janeiro, Brazil. Cad Saúde Pública. 2009; 25(3):635-44.

21. Arbex MA, Bohn GM, Saldiva PHN, Conceição GMS, Pope AC, Braga ALF Assessment of the effects of sugar cane plantation burning on daily counts of inhalation therapy. J Air Waste Manag Assoc. 2000; 50(10):1745-9.

22. Arbex MA. Avaliação dos efeitos do material particulado proveniente da queima da plantação de cana-de-açúcar sobre a morbidade respiratória na população de Araraquara-SP. [Thesis]. São Paulo: Faculdade de Medicina, Universidade de São Paulo, 2002.
23. Gouveia N, Freitas CU, Martins LC, Marcilio IO. Respiratory and cardiovascular hospitalizations associated with air pollution in the city of São Paulo, Brazil. Cad Saúde Pública. 2006; 22(12):2669-77.

24. Jasinski R, Pereira LA, Braga AL. Air pollution and pediatric hospital admissions due to respiratory diseases in Cubatão, São Paulo state, Brazil, from 1997 to 2004. Cad Saúde Pública. 2011; 27(11):2242-52.

25. Moura M, Junger WL, Mendonça GA, Leon AP. [Air quality and acute respiratory disorders in children. Rev Saúde Pública]. 2008; 42(3):503-11.

26. Amancio CT, Nascimento LFC. Asma e poluentes ambientais: um estudo de séries temporais. Rev Assoc Med Bras. 2012; 58(3):302-7. 